\title{
Water Pollution of Oued Medjerda in Algerian Souk Ahras Region
}

\author{
A. Nait Merzoug 1,2 and H. Merazig 2 \\ ${ }^{1}$ Laboratory of Science and Techniques of Water and Environnement, \\ University Center Mohamed Cherif Messadia, Souk Ahras, \\ ${ }^{2}$ Research Unit of Environnemental Chemistry and Structural Molecular Chemistry, \\ Department of Exact Sciences Faculty, Mentouri University, \\ Route de Ain El Bey, Constantine, \\ Algeria
}

\section{Introduction}

Water has a fundamental impact on the economy and it is at the center of strategic interests. It is is an essential element of daily life for each and every one of us and a vital source of wealth and can become a possible destabilizing factor for the countries of the disinherited areas. The water provision is becoming more and more alarming which is due the galloping demography and the increasing droughts during these last years. In 2002, 1.5 million humans did not have access to safe drinking water and 2.5 million individuals in the world did not benefit from cleansing service (Phiri, 2005), (Lefort, 2006).

Algeria is one of the most underprivileged areas in the world with regard to hydrous availability (A. N. B. 2001). Furthermore, the demographic explosion and the economic growth led to a very high water demand which by far exceeds the available resources (Ajayi, 2002), the annual availability of water in east-Algeria is $600 \mathrm{~m}^{3}$ / inhabitant year. This places it in the poor category countries in hydrous resources with respect to the rarity threshold level, fixed by the World Bank, of 1000 m³/inhabitant year (A. N. B. 2001), (Bouchentouf, 1994).

The strategy of any developing region in a country must necessarily be based primarily on "The control of water resources," they must be translated into a rational, continuous and sustainable water potential in the socio-economic order. Faced with ever-increasing challenges of water resource management in the country, a coherent politic of water at the national level is essential. Where with the development of the urbanization and the industrialization, as well as the evolution of consumption modes the discharges of waste water were considerably evolved in quantity and in quality. So sewer systems collect all the varieties of discharges such as domestic, industrial and commercial discharges with very diverse characteristics. The aim of the wastewater treatment was to reduce the pollution load they carry in order to protect the receiving natural environment such us sea water, oued...etc. and eventually for its future uses (fishing, leisure, food, agricultural or industrial use, etc.). 
From this perspective our contribution will be particularly focused on the impact of residual treated wastewater from the sewage treatment plant (STEP) of Hennencha (Souk Ahras) on the water quality of Oued Medjerda, Principal River in the region, and eventually of Ain Dalia Dam.

Souk Ahras city is located at north east of Algeria and extends on a surface of $4360 \mathrm{~km}^{2}$. It has four dams and an exclusive dependence on Medjerda River for its provision (ANRH, 2003). This natural water source is the principal river of the Maghreb region by its flow length as well as its area and the water volume procured (Derradji, 2004), (Louis, 1956).

\section{Materials and methods}

\subsection{Study area}

The low plain of Medjerda is situated in the north east of Algeria, at $680 \mathrm{~km}$ from Algiers and at $100 \mathrm{~km}$ from Annaba. The Medjerda River crosses the territories of two states: Algeria in its high part and Tunisia in its average and low parts. It takes its source from Khemissa, runs towards the east before discharging its contents in the Mediterranean sea, in the "golf of Tunis" (Figure. 1). It extends on $416 \mathrm{Km}, 106 \mathrm{Km}$ of which depend on the authority Souk Ahras city (Athmani, 2005). The river displays a flow that widely varies with the season, ranging from $1000 \mathrm{~m}^{3} / \mathrm{s}$ at winter to $1 \mathrm{~m}^{3} / \mathrm{s}$ at summer (A.B.H. 2001). The population of the studied area reaches more than 120000 inhabitants.

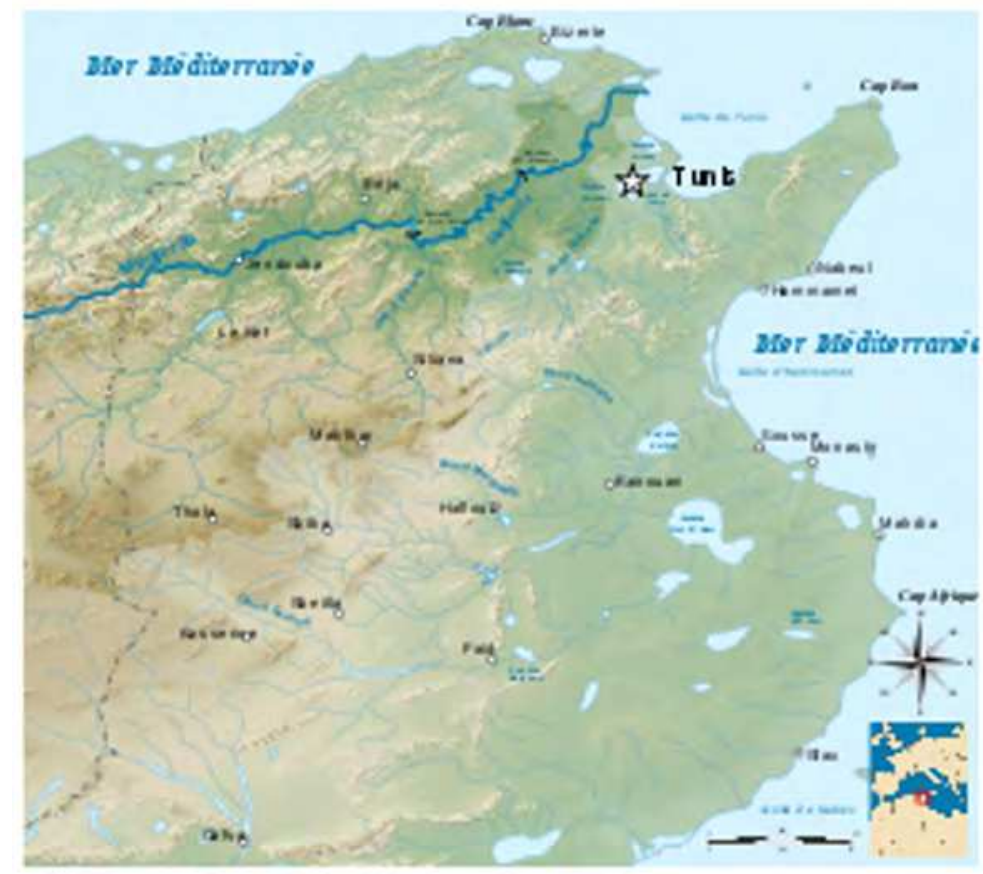

Fig. 1. Localization on map of Medjerda River (Elkenedj, 2009). 
Realized in 1991 for a capacity of $200 \mathrm{~m}^{3}$ /day, the treatment plant of waste water (STEP of Henancha) receives currently more than $774 \mathrm{~m}^{3}$ / day causing serious water quality problems in Oued Medjerda which is the first receiver of the STEP rejections and also on the water quality of Ain Dalia dam located at $600 \mathrm{~m}$ downstream from STEP.

Geographical location:

The commune of Hennencha is located at $15 \mathrm{~km}$ at the West of Souk Ahras city. It is localised with the Lambert coordinates (Northern Algeria): $X=96,977 \mathrm{Km}$; $Y=340,349 \mathrm{Km}$ figureN0 2 .

\subsection{Sampling}

Samples from the Medjerda River were taken from sites A and E respectively located upstream upstream and downstream the STEP. However, both sites are situated upstream the Ain Dalia dam. The sampling procedure was carried out once a month from Mars to July 2009.

\subsection{Sampling procedure and material}

The samples were taken in PVC 2-liter bottles. Before use, the bottles were treated with nitric acid, rinsed with distilled water and dripped before being washed three times with the water to be analyzed.

The sampling was carried out manually from the two fixed intake points. The bottle was held with one hand, immersed to a $20 \mathrm{~cm}$ depth, filled with water and hermetically closed. Then the samples were carefully and promptly transported to the laboratory after collection at a temperature of $4^{\circ} \mathrm{C}$ in order to ensure the physico-chemical parameters.

\subsection{Chemical and physical analysis}

The knowledge of some basic physical and chemical parameters offers a preliminary estimation of the water quality and the extent of eventual contamination. The physicochemical parameters were determined by standard chemical and instrumental methods.

The suspended Matter (SM) in water after and before STEP rejections was determined using centrifugation. A sample of $100 \mathrm{ml}$ of water is poured into the cup and centrifuged for 20 $\mathrm{min}$ at $3000 \mathrm{tr} / \mathrm{min}$. The reaping cullet centrifuge is placed in a porcelain dish and dried to constant weight at $1050 \mathrm{C}$. After drying, the dish is placed in the desiccator for one hour and then it is weighed quickly.

Chemical Oxygen Demand (COD) is measured by colorimetric method after digestion of the sample for two hours in a COD reactor (DCO Spectrophotometer DREU2010 Adapteur de tube DCO sur DREL12010). When the biochemical oxygen demand (BD05) is defined as the amount of oxygen consumed speaks aerobic micro-organisms for the decomposition of biodegradable organic matter in the water to be analyzed for a period of five days.

The sample is stirred in a flask sealed incubator connected to a mercury manometer During biodegradation of organic matter, microorganisms consume oxygen from the air in the bottle causing a reduction in pressure above the sample. This vacuum is transmitted to the mercury manometer and oxygen consumption and read on the scale gauge. 


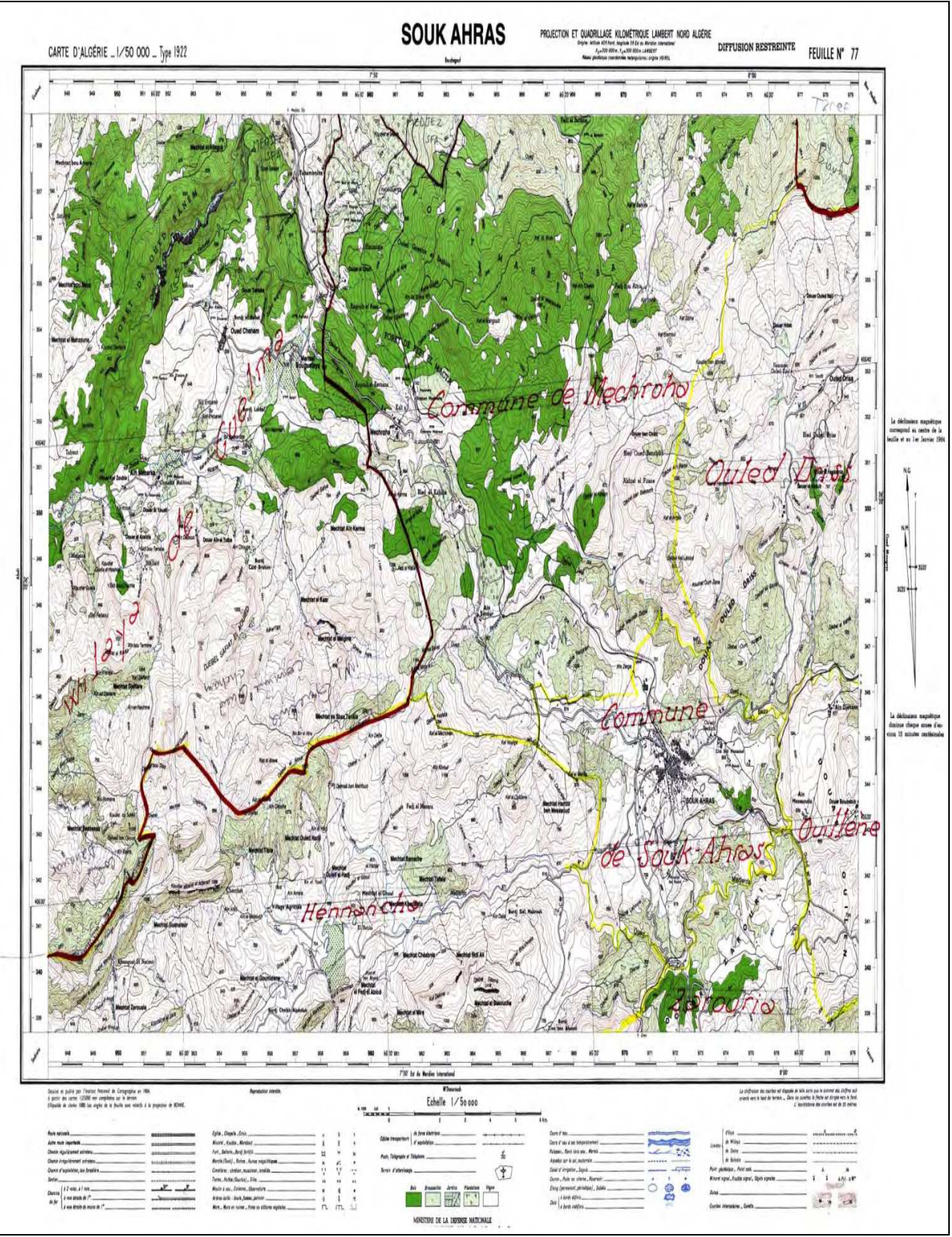

Fig. 2. Geographic area of Souk Ahras(Elkenedj, 2009).

So, we used colorimetric methods in order to quantify the major elements $\left(\mathrm{NH}_{4}{ }^{+}, \mathrm{NO}_{2}{ }^{-}\right.$, $\mathrm{NO}_{3}^{-}$). For each determination, a water volume of $20 \mathrm{ml}$ was mixed in a cell with the suitable 
reagent $\mathrm{HACH}$. The unit was stirred and then left at rest for a pre-determined time to allow the complete colour-making reaction of the analyte with the reagent. The cell was then placed in a calibrated spectrophotometer, previously set at the wavelength of maximum absorbance. The quantification of the heavy metals lead $(\mathrm{Pb})$ and cadmium $(\mathrm{Cd})$ and selenium (Se) was carried out by a Lovibond spectrophotometer. The methods of analysis of the remaining parameters are gathered on the (Table. 1).

\begin{tabular}{|c|c|}
\hline Temperature & Thermometer \\
\hline pH & Potentiometry \\
\hline COD & Reflux method \\
\hline BDO $_{5}$ & 5- days incubation \\
\hline Suspended matter & Gravimetric \\
\hline Nitrates & Colorimetric method \\
\hline Nitrites & Colorimetric method \\
\hline Ammonium ions & Colorimetric method \\
\hline Lead & Photometric method \\
\hline Cadmium & Photometric method \\
\hline Selenium & Photometric method \\
\hline
\end{tabular}

Table 1. Water quality test methods.

\section{Results and discussion}

The results of the physico-chemical analyses of the Medjerda water before and after the STEP effluent input (site E and A respectively) are reported on Tables $\mathbf{2}$ and $\mathbf{3}$ respectively.

\begin{tabular}{|l|c|c|c|c|c|c|c|c|c|c|c|}
\hline Period & $\begin{array}{c}\mathbf{T} \\
\left({ }^{\circ} \mathbf{C}\right)\end{array}$ & $\mathbf{p H}$ & $\begin{array}{c}\mathbf{S M} \\
(\mathbf{m g} / \mathbf{l})\end{array}$ & $\begin{array}{c}\mathbf{C O D} \\
(\mathbf{m g} / \mathbf{l})\end{array}$ & $\begin{array}{c}\mathbf{B D O}_{5} \\
(\mathbf{m g} / \mathbf{l})\end{array}$ & $\begin{array}{c}\mathbf{N O}_{3^{-}} \\
(\mathbf{m g} / \mathbf{l})\end{array}$ & $\begin{array}{c}\mathbf{N O}_{2^{-}} \\
(\mathbf{m g} / \mathbf{l})\end{array}$ & $\begin{array}{c}\mathbf{N H}_{4}{ }^{+} \\
(\mathbf{m g} / \mathbf{l})\end{array}$ & $\begin{array}{c}\mathbf{P b} \\
(\mathbf{m g} / \mathbf{l})\end{array}$ & $\begin{array}{c}\mathbf{C d} \\
(\mathbf{m g} / \mathbf{l})\end{array}$ & $\begin{array}{c}\mathbf{S e} \\
(\mathbf{m g} / \mathbf{l})\end{array}$ \\
\hline March & 18.5 & 7.60 & 19 & 11 & 1.4 & 0.006 & 0.002 & 0.008 & 0.01 & 0.08 & $/$ \\
\hline April & 18.5 & 7.39 & 25.5 & 82.2 & 4.6 & 5.4 & 0.04 & 0.11 & 0.76 & 0.09 & $/$ \\
\hline May & 19.7 & 7.77 & 31.6 & 9 & 2 & 1.9 & 0.003 & 0.12 & 0.85 & 0.09 & $/$ \\
\hline June & 20.3 & 7.81 & 40.5 & 25 & 15 & 1.7 & 0.002 & 0.12 & 1.18 & 0.10 & $/$ \\
\hline July & 24.8 & 7.52 & 55 & 37 & 19 & 0.7 & 0.001 & 0.13 & 1.44 & 0.18 & $/$ \\
\hline $\begin{array}{l}\text { Limiting } \\
\text { values }\end{array}$ & 30 & $7-9$ & 30 & 120 & 40 & 50 & 0.1 & 0.5 & 0.03 & 0.01 & $/$ \\
\hline
\end{tabular}

Table 2. Water parameters at site E (upstream STEP).

\begin{tabular}{|l|c|c|c|c|c|c|c|c|c|c|c|}
\hline Period & $\begin{array}{c}\mathbf{T} \\
\left({ }^{\circ} \mathbf{C}\right)\end{array}$ & $\mathbf{p H}$ & $\begin{array}{c}\mathbf{S M} \\
(\mathbf{m g} / \mathbf{l})\end{array}$ & $\begin{array}{c}\mathbf{C O D} \\
(\mathbf{m g} / \mathbf{l})\end{array}$ & $\begin{array}{c}\mathbf{B D O}_{\mathbf{5}} \\
(\mathbf{m g} / \mathbf{l})\end{array}$ & $\begin{array}{c}\mathbf{N O}_{3^{-}} \\
(\mathbf{m g} / \mathbf{l})\end{array}$ & $\begin{array}{c}\mathbf{N O}^{-} \\
(\mathbf{m g} / \mathbf{l})\end{array}$ & $\begin{array}{c}\mathbf{N H}_{4}{ }^{+} \\
(\mathbf{m g} / \mathbf{l})\end{array}$ & $\begin{array}{c}\mathbf{P b} \\
(\mathbf{m g} / \mathbf{l})\end{array}$ & $\begin{array}{c}\mathbf{C d} \\
(\mathbf{m g} / \mathbf{l})\end{array}$ & $\begin{array}{c}\mathbf{S e} \\
(\mathbf{m g} / \mathbf{l})\end{array}$ \\
\hline March & 18.2 & 7.47 & 66.5 & 118 & 45.8 & 0.7 & 0.26 & 2.64 & 0.04 & 0.123 & $/$ \\
\hline April & 18.4 & 7.19 & 90.5 & 296 & 47 & 9.4 & 0.68 & 5.92 & 1.84 & 0.133 & $/$ \\
\hline May & 20.3 & 7.50 & 109.6 & 132 & 33 & 2.6 & 0.37 & 6.82 & 1.86 & 0.169 & $/$ \\
\hline June & 21 & 7.88 & 154.5 & 144 & 75 & 2.3 & 0.14 & 7.14 & 1.95 & 0.172 & $/$ \\
\hline July & 25.1 & 7.72 & 155 & 158 & 145 & 1.9 & 0.006 & 11.92 & 2.08 & 0.280 & $/$ \\
\hline
\end{tabular}

Table 3. Water parameters at site A (downstream STEP). 


\subsection{Temperature}

The water temperature plays an important role in the solubility of salts and gases. As reported in (figure. 3) the maximal temperatures were recorded in July, specifically $25,1^{\circ} \mathrm{C}$ at site $\mathrm{A}$ and $24,8{ }^{\circ} \mathrm{C}$ at site $\mathrm{E}$. The temperatures observed at the both was lower than the Algerian standards; we may recall that temperatures higher than $15^{\circ} \mathrm{C}$ favor the development of micro-organisms and in the same time intensify the organo-leptical parameters like odor and activate chemical reactions (Athmani, A. S. 2005), (Guasmi, 2004), ( Botton et all. 1999), ( Meinck et all. 1977).

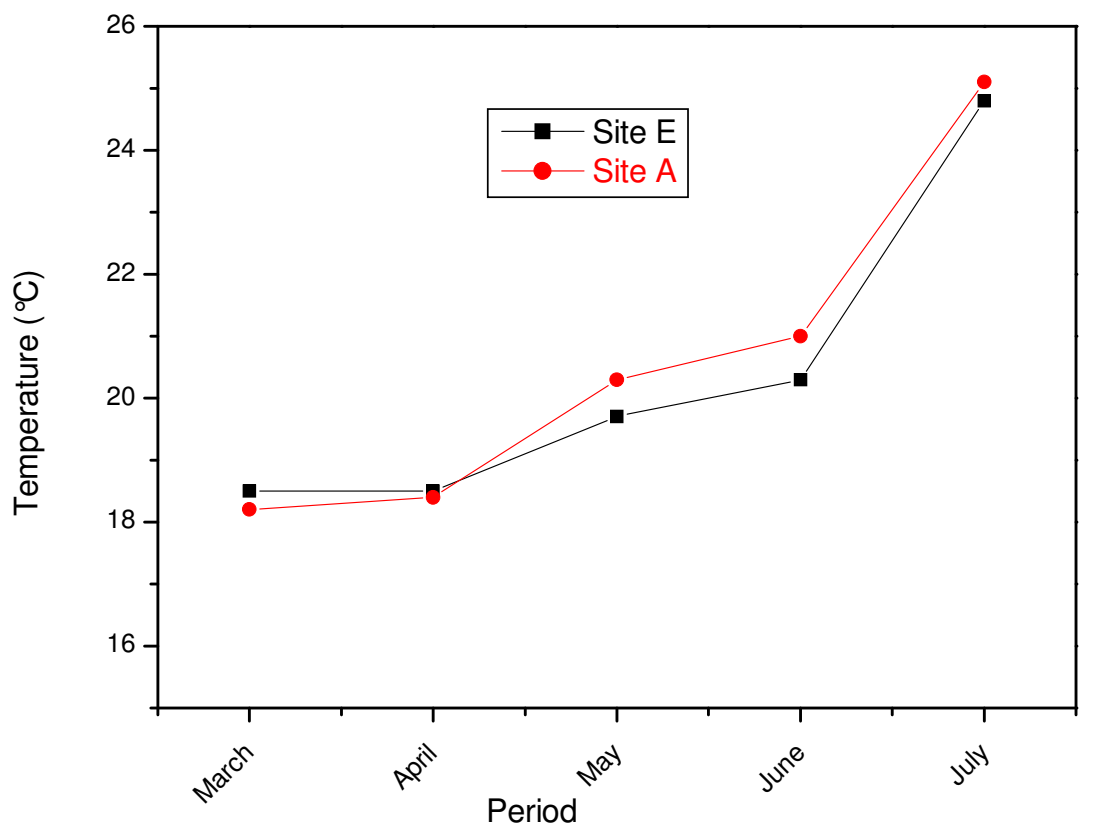

Fig. 3. Temperature variations before and after the intake of STEP effluent as a function of time.

\section{$3.2 \mathrm{pH}$}

The $\mathrm{pH}$ is also a factor which influences the biological activity of the water micro flora. As seen on (figure 4) all samples from both sites display a slightly basic $\mathrm{pH}$, ranging from 7,4 to 7,9 in the first site and from 7,1 to 7,9 in the second one. Generally, the obtained values were in agreement with the Algerian and the word health organization standards of 7,0 to 8,5. A neutral $\mathrm{pH}$ in the interval $(6.5$ - 8.5) characterizes water where life develops in optimal way (Larpent, 1997), (Guasmi \& Djabri, 2006).

\subsection{Suspended matters}

To appreciate a water quality; it is always necessary to estimate quantitatively its load in dissolved and particular matter. As shown in (Figure. 5) we notice that the contents in 
suspended matter (SM) are more raised in the site A than in the site $\mathrm{E}$ and the values vary from 19 to $55(\mathrm{mg} / \mathrm{g})$ in the first one and from 66,5 to 155 in the second.

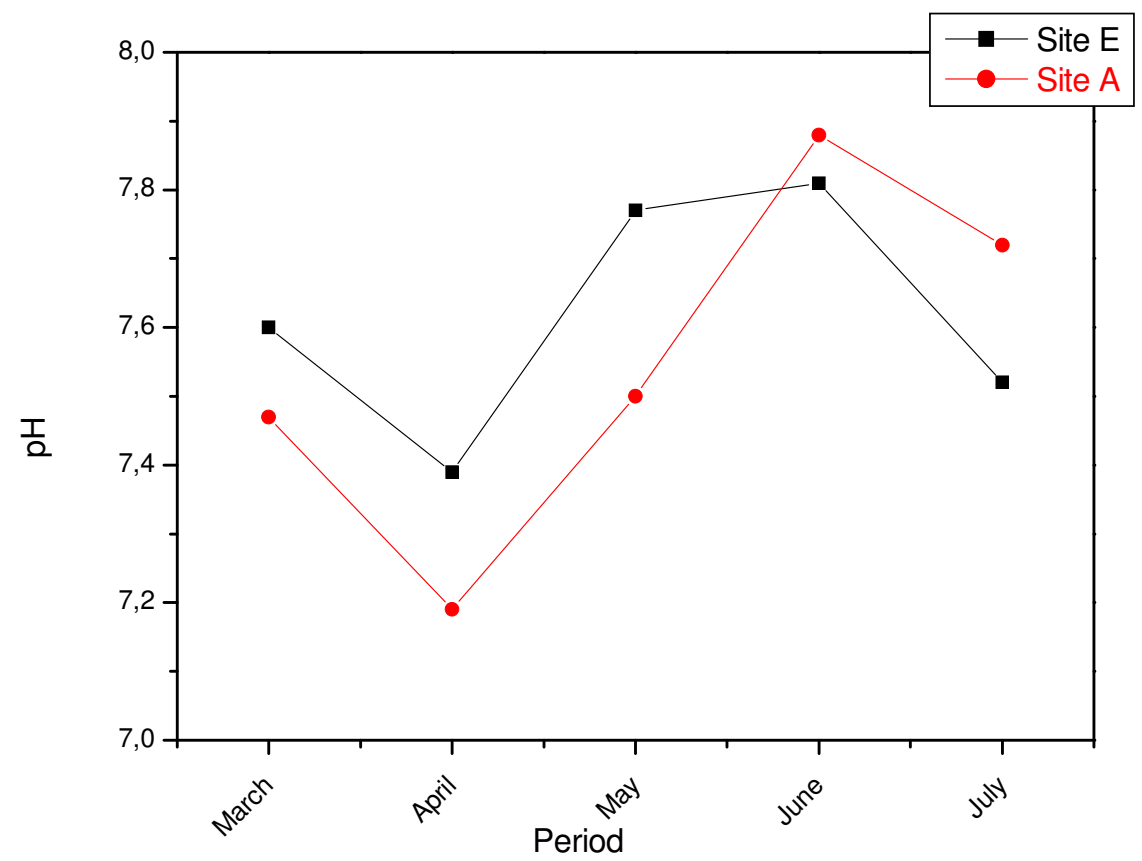

Fig. 4. $\mathrm{pH}$ variations before and after the intake of STEP effluent as a function of time.

We also noticed that the suspended matter content varies significantly with the season and the rates are higher in dry period than in pluvial one.

As soon as suspended matter content exceeds the Algerian standards in site A and that can induce the accumulation of higher quantities of toxic substances such as metals, pesticides, mineral oils, polycyclic aromatic hydrocarbons (Tiri et all. 2007), (Derradji et all. 2007), (Abulude et all. 2007), (Bouchenafa et all. 2008)which may have an adverse effect on water quality.

\subsection{Chemical oxygen demand (COD) and biological demand of oxygen $\left(\mathrm{BDO}_{5}\right)$}

The Chemical Oxygen Demand (COD) is the amount of oxygen consumed in $\mathrm{mg} / \mathrm{l}$, for oxidable materials in an effluent. It is representative of most of organic compounds but also oxidable inorganic salts (sulfides, chlorides...).

As shown in (Figures. 6) we noticed that values of chemical oxygen demand are lower than the Algerian standards in the site E but higher in the site A. We also note that most of the values exceed the Algerian standards in the site A for a maximum of $296 \mathrm{mg} / \mathrm{I}$. This allows to classifying the water of this site as very bad quality. On the other hand, the high temperatures of the warmest months and also the dry periods of the year, seem to increase significantly the COD of these water. 


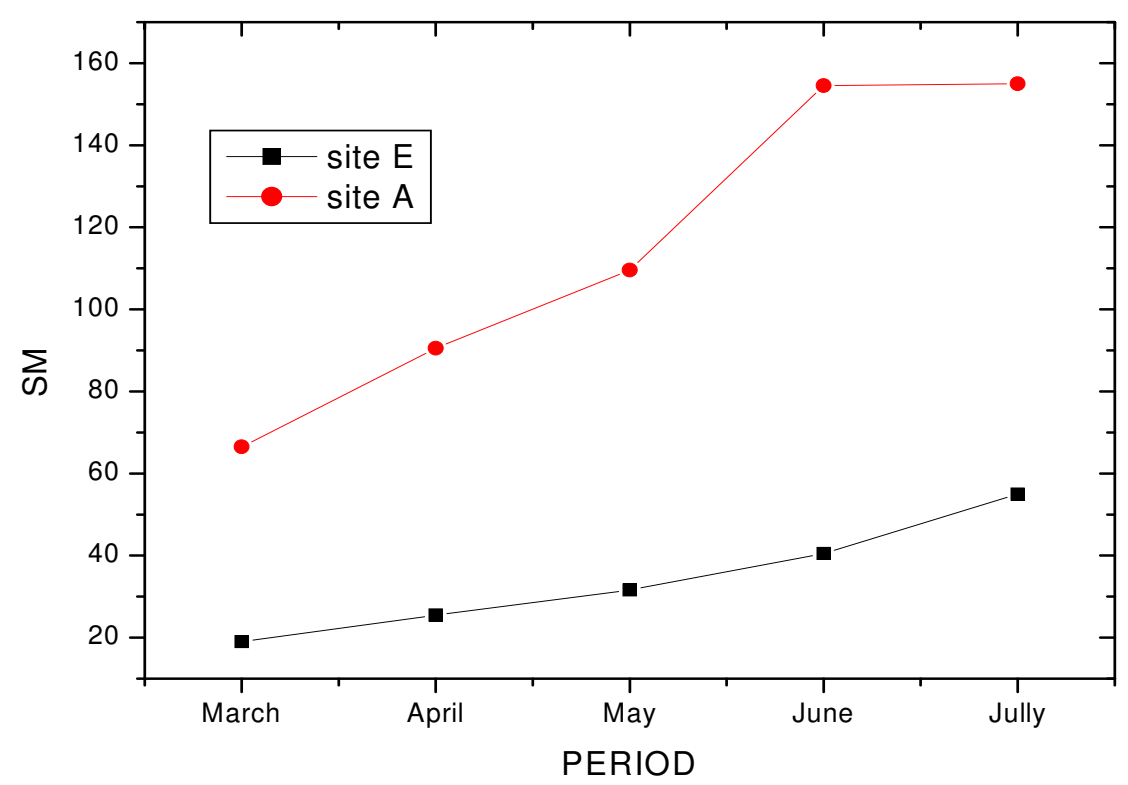

Fig. 5. Total suspended solids variations before and after the intake of STEP effluent as a function of time.

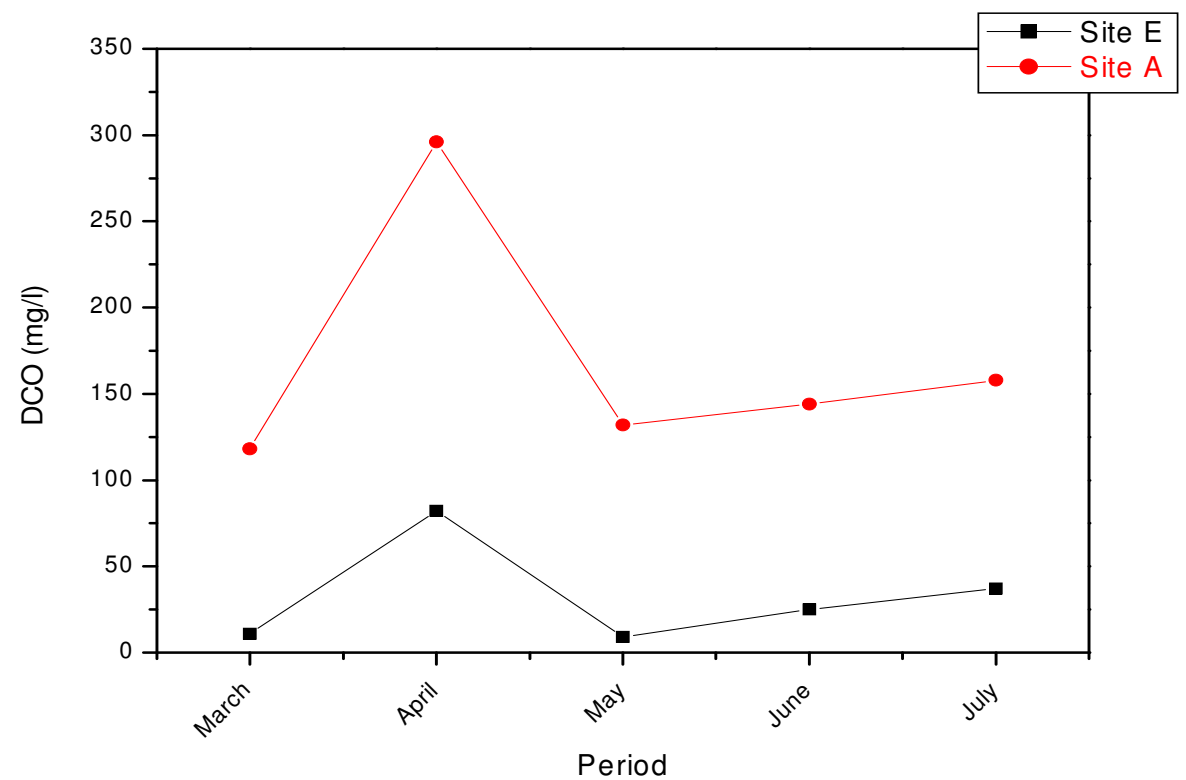

Fig. 6. Variations of chemical oxygen demand before and after the intake of STEP effluent as a function of time. 
The biochemical oxygen demand $\left(\mathrm{BDO}_{5}\right)$ allows the evaluation of the present biodegradable organic matters in water. (Figure 7 ) showed that the $\mathrm{BDO}_{5}$ values are lower than the Algerian standards in the site $\mathrm{E}$ but exceed them in the site $\mathrm{E}$ only in dry period and this is in agreement with the results obtained by Guasmi et Djabri...etc (Guasmi \& Djabri, 2006), (Tiri et all. 2007), (Benzha et all. 2005), (Guasmi \& Djabri, 2005).

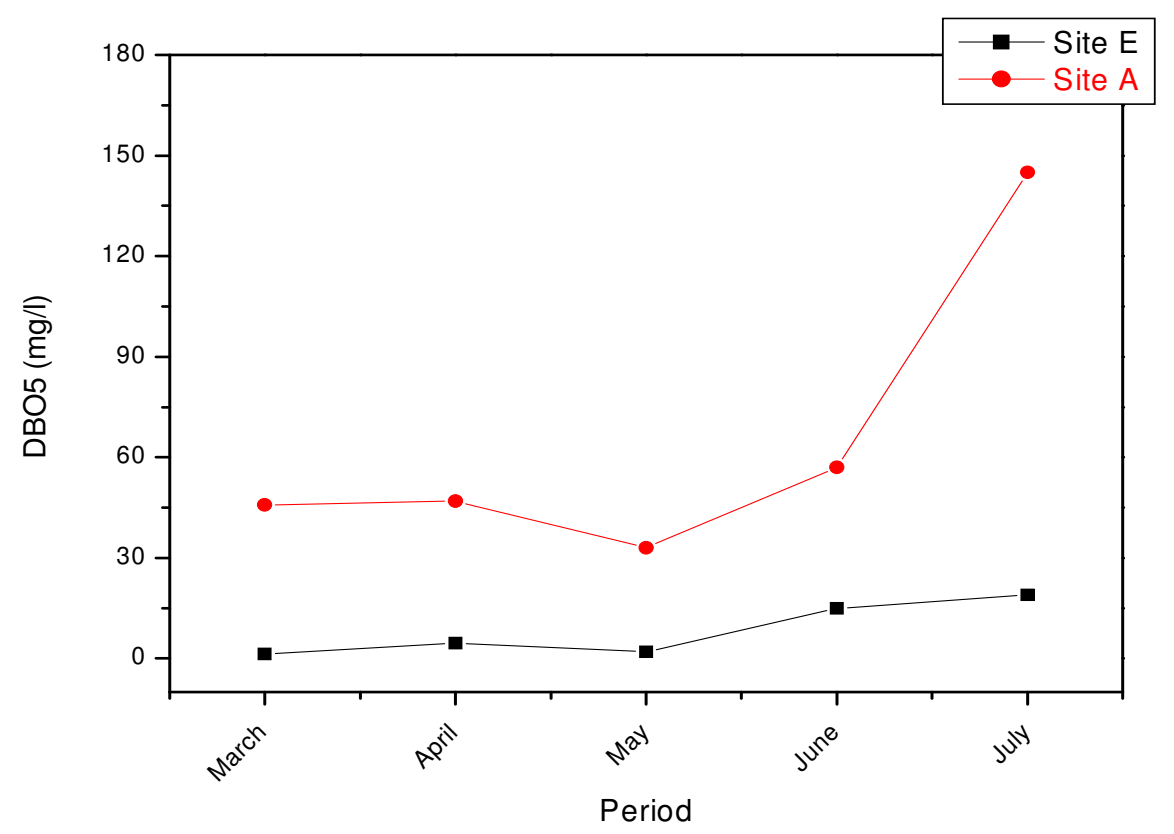

Fig. 7. Variations of biochemical oxygen demand before and after the intake of STEP effluent as a function of time.

\subsection{Dissolved nitrogen}

Human activities and mainly those related to agriculture are a major cause of the presence of nitrates and nitrites in surface water. These two substances are responsible for many problems not only for environment but also for human health. Indeed, although not directly toxic, they participate in eutrophication phenomena of surface water.

The made analyses allow to notice that the rates of nitrates obtained in the two sites are lower than the standards required which are in the order of $50 \mathrm{mg} / 1$ (Figures 8, 9 and 10). On the other hand the results concerning nitrites and ammonium ion show superior rates to the standards required $(0,1 \mathrm{mg} / \mathrm{l})$ at the site A. Their presence can be explained by an incomplete oxidation of the ammonia water; or a nitrate reduction reaction. This pollution can be caused by intense agricultural activity (the region of study is known for its agricultural vocation) and misuse of chemical fertilizers around the sewage waste water and Oued Medjerda. 


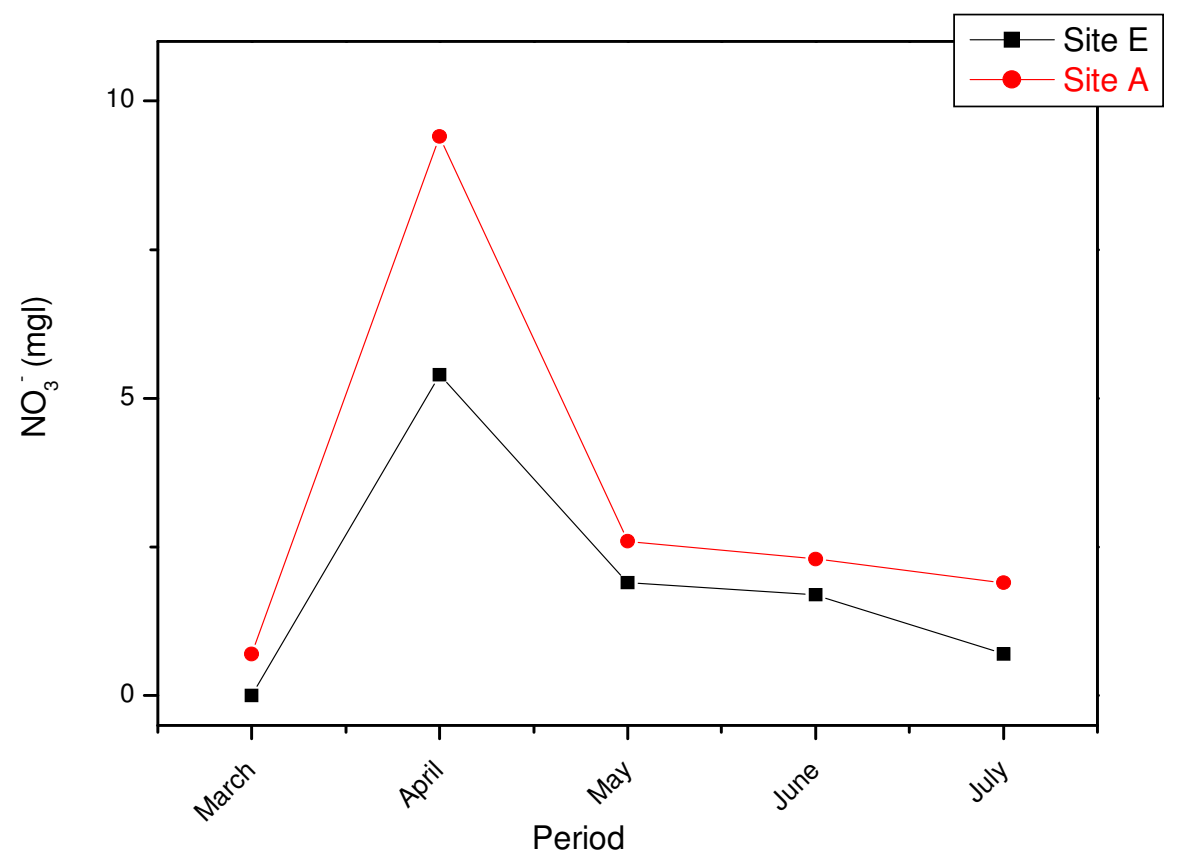

Fig. 8. Nitrates variations before and after the intake of STEP effluent as a function of time.

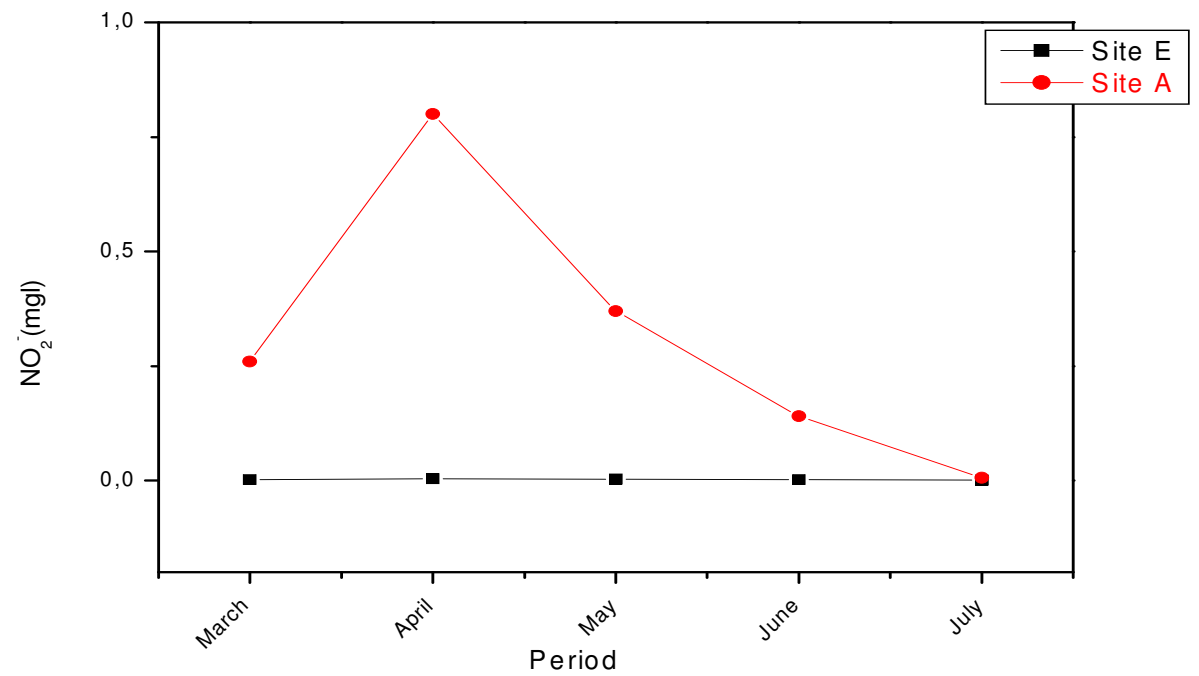

Fig. 9. Nitrites variations before and after the intake of STEP effluent as a function of time. 


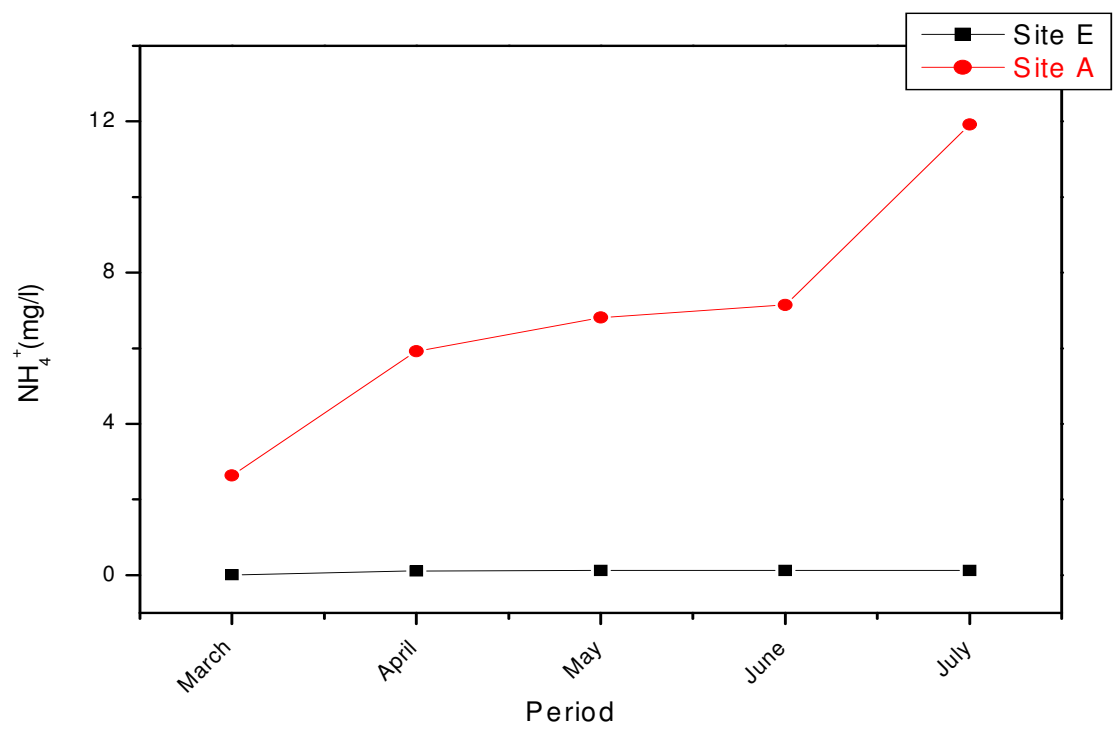

Fig. 10. Ammonium ion variations before and after the intake of STEP effluent as a function of time.

The highest contents of nitrates and nitrites are observed in April and may be explained by the leaching by rainfall observed at this precipitation period. The highest ammonium concentration is observed in July and may be explained by a dilution effect, the water volume flowing in the river being much lower in this dry period (Derradji et all. 2007), (Abulude et all. 2007), (Bouchenafa et all. 2008).

\subsection{Metals}

It has been clearly demonstrated that serious environmental problems were caused when the waste or the treated water may contain high levels of trace elements. These elements are potentially toxic to plants and human beings. How ever the case of selenium is complex since it is at the same time a trace element; essential to life; and a toxic; and this in a narrow range of concentration.

According to the results obtained (figure 11 and 12) we noticed that lead $(\mathrm{Pb})$ levels Varied between 0,01 to $1,44 \mathrm{mg} / \mathrm{l}$ in the first site and from 0,04 to $2,08 \mathrm{mg} / 1$ in the second one which are within acceptable limit value of $0,03 \mathrm{mg} / 1$. Similarly for cadmium (Cd), its concentration varies from $0,08 \mathrm{t}$ o $0,18 \mathrm{mg} / 1$ in the site $\mathrm{E}$ and from 0,11 to $0,3 \mathrm{mg} / 1$ in the site $\mathrm{A}$, whereas the limit value is $0,01 \mathrm{mgl} /$. while this is not the case for selenium (Se). For which we noted its non-existence.

So we can say that there is a generated pollution by metals such as lead and cadmium. With high levels in the site A and less in the site E. The high content in of metals is probably due to the direct pollution of the rivers by the industrial wastes; atmospheric precipitation involving a certain part of the pollutants present in the atmosphere and in consequence of the streaming of water on the grounds involving accumulated lead or cadmium at surface (Abulude et all. 2007), (Igbinosa \& Okoh, 2009). 


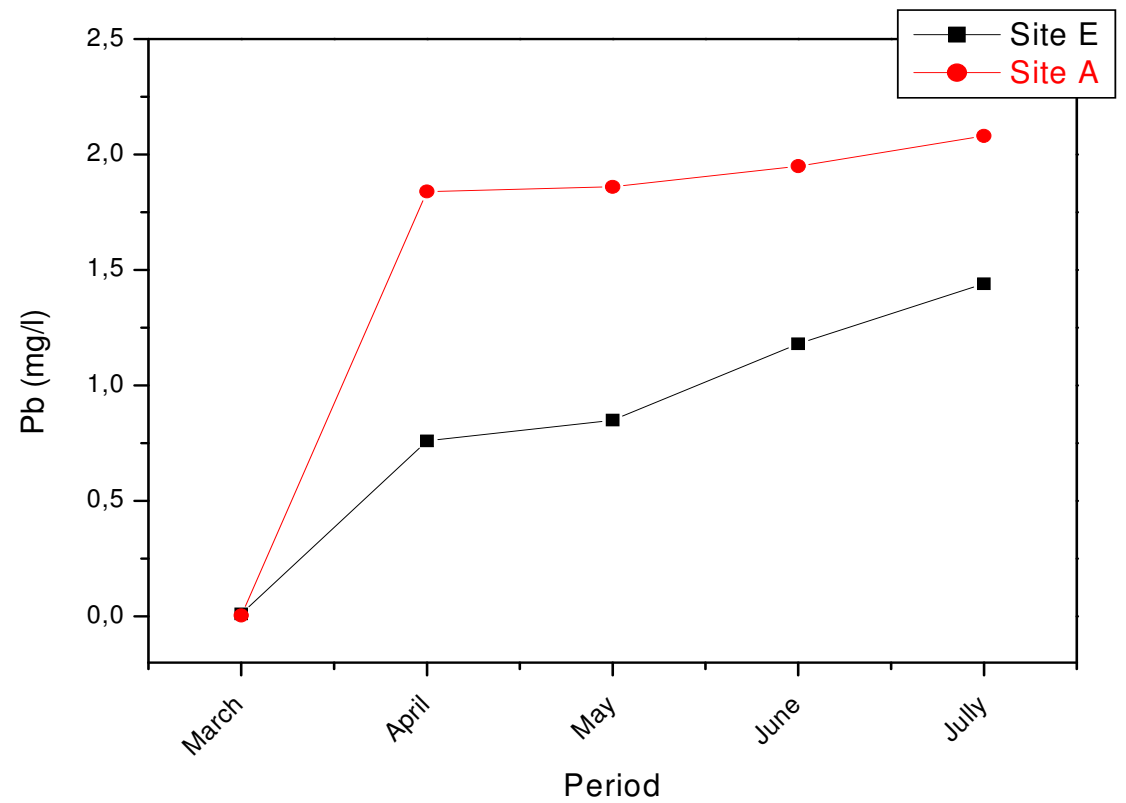

Fig. 11. Lead variations before and after the intake of STEP effluent as a function of time.

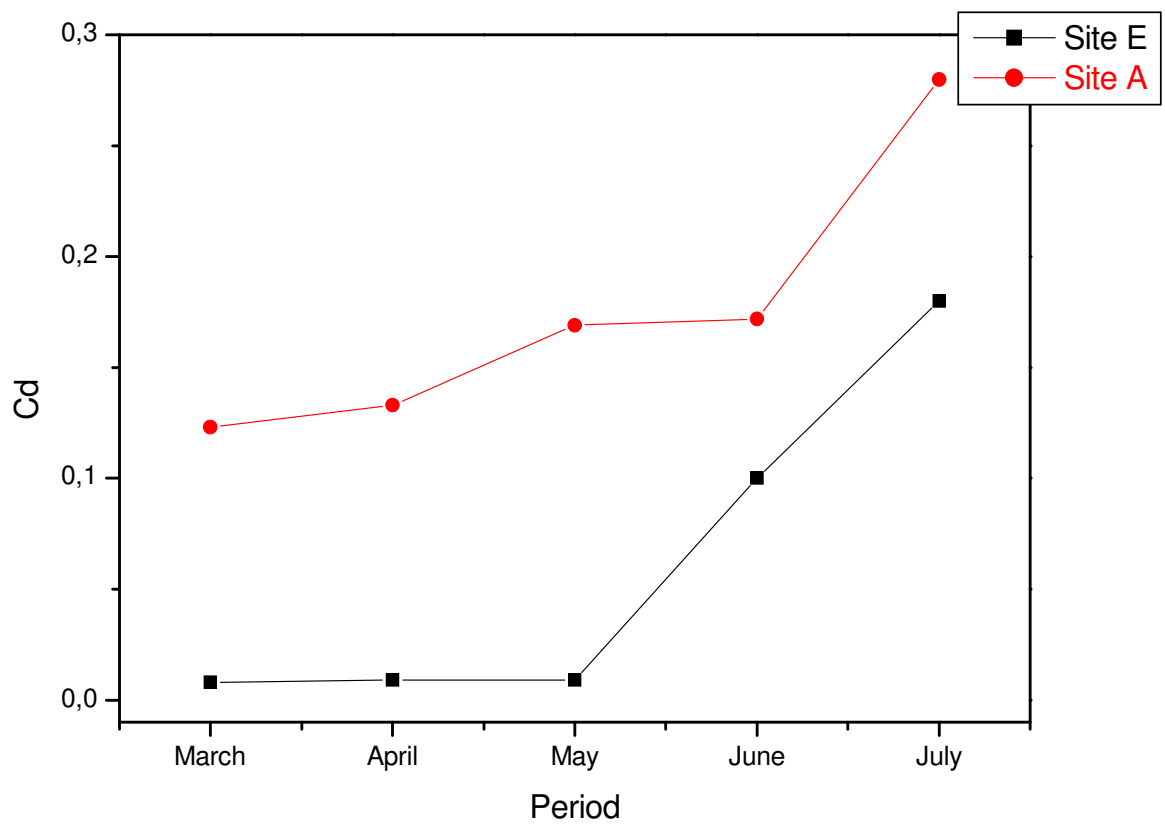

Fig. 12. Cadmium variations before and after the intake of STEP effluent as a function of time. 


\section{Conclusion}

Medjerda is the principal river in the north-east of Algeria. This study examines the impacts of discharges of sewage wastewater (STEP Henencha) on the quality of this river. Monitoring was made upstream and downstream the STEP rejections from March to July 2009. Parameters measured include $\mathrm{pH}$, temperature, total suspended matters, chemical oxygen demand, biological oxygen demand, nitrate, nitrite, ammonium ions and trace elements (cadmium, lead and selenium) using standard methods. Unacceptably, high levels of the assayed parameters were observed downstream the STEP in many cases for chemical oxygen demand (118- $296 \mathrm{mg} / \mathrm{l})$, biological oxygen demand (33- $145 \mathrm{mg} / \mathrm{l})$, nitrite $(0,14-0,68$ $\mathrm{mg} / \mathrm{l})$, ammonium ions (2,64- 11,92 mg/ l); lead (0,04- 2,08 mg/ l) and cadmium (0,1- 0,2 mg/ 1) during the study period and outside the compliance levels of Algerian guidelines. We can also conclude that the lowest levels of metal ions were registered during flood periods and this is certainly due to the high dilution facing the river following rainfall. The results obtained confirmed that there was an adverse impact on the physico-chemical characteristics and this implies that the water of this river has a major pollution problem.

\section{Abbreviations}

STEP Henancha : Wastewater treatment station of Henancha

COD: Chemical oxygen demand

$\mathrm{BDO}_{5}$ : Biological oxygen demand

$\mathrm{SM}$ : Suspended matter

$\mathrm{NH}_{4}{ }^{+}$: Ammonium ions

$\mathrm{NO}_{2}:$ Nitrites

$\mathrm{NO}_{3}:$ : Nitrates

$\mathrm{Pb}$ : Lead.

Cd: Cadmium.

Se: Selenium.

\section{References}

Abulude, F. O. Obidiran, G. O \& Orungbemi, S (2007). Determination of physico-chemical parameter and trace metal contents of drinking water samples in Akure Nigeria, EJEAF che, Vol. 6, N0 8, pp. 2297-2303

ANRH: Agence Nationale des ressources hydriques (2003). Page Web. www.anrh.dz.

Ajayi, O.O., J. Ogun, and I.I. Oguntimehin. (2002). “The Influence of Waste Dumps on Some Underground Water Sources in Warri". Journal of Science Laboratory Technology International. VOL.1, N01. In Press.

Athmani, A. S. (2005). Evaluation de la qualité des eaux de surface, cas du bassin versant Oued Medjerda (Souk Ahras, Algérie), Thèse de Magister, Centre universitaire de Souk Ahras

Benzha, F. Taoufik, M. Dafir, J.E. Kemmou, S. \& Loukili, L (2005). Impact of drainage operation on water quality of Daourat Reservoir, Rev. Sci.Eau N018, pp. 57-74.

Bouchenafa, N. Abdelkader, D. \& Maatoug.,M. (2008). Water pollution of Oued Mina under catchments, in Algerian Tiaret region. Ass. Univ. Bull. Environ. Res. Vol.11 N02, pp. 43-51. 
Botton, B. Bretton, A. Fevre, M. Gauthier, S. Guy, Ph. Larpent, JP. Reymond, P. Sanglier, J.J. Vayssier, Y.\& Veau, P. (1999). Moisissures utiles et nuisibles: importance industrielle. Collection Biotechnologiques. Ed Masson, p p. 97-213-216-219.

Bouchentouf, K. (1994). Les bilans d'eau vus à travers les paramètres physico-chimiques et hydrodynamiques: cas du basin versant de la haute Mina (Tiaret, Algérie), Thèse de Magister. Centre universitaire de Chelef, Algeria.

Derradji, F. (2004). Identification quantitative et qualitative des ressources en eau dans la région d'Annaba (El Tarf, Algérie). Doctorat des sciences, Université de Annaba, Algérie

Derradji, F. Ben snoubra, H. Kherici, N. Romeo, M. Karuba, R. (2007). Impact de la pollution organique sur la qualité des eaux superficielles dans le nord est algérien, Sécheresse Vol.18, N01, pp. 23-27

Document inédit: Agence National des barrages, (2001).Algérie

Elkenedj, Y.B. (2009). Etude de l'effet de l'aération naturelle sur la pollution résiduaire des eaux épurées de la zone de l'Hennencha W. Souk Haras (N.E.Algérien), Thèse de Magister, Université Badji Mokhtar Annaba, Algérie

Guasmi, I. (2004). Dégradation de la qualité de l'eau dans le bassin versant de l'Oued Medjerda (Souk Ahras, Algérie), Thèse de Magister, Université de Annaba, Algérie

Guasmi, I. Djabri, L (2005). L'évolution des nitrates, nitrites et ammonium dans les eaux de surface de l'oued Medjerda (Souk Ahras). 3 éme journée des géosciences de l'environnement, El Jadida les 8, 9 et 10 juin. Tunis

Guasmi, I.\& Djabri, L. (2006). Pollution des eaux de l'Oued Medjerda par les nutriments. Larhyss Journal N05,pp. 113-119.

Igbinosa, E.O., Okoh, A.I. (2009). Impact of discharge wastewater effluents on the physicochemical qualities of a receiving watershed in a typical rural community. Int. J. Environ. Sci. Tech., Vol.6, N0 2, pp.175-182, Spring 2009, ISSN: 1735-1472

Louis, D. (1956). Etude géologique des monts de la haute Medjerda, Thèse SC. Science de la carte géologique de l'Algérie, Algérie

Lefort, R. (2006). "Down to the Last Drop". UNESCO Sources. 84.

Meinck, F. Stoof, H. Kohlschutter. (1977). H. Les eaux résiduaires industrielles, 2eme Ed. Masson, Paris, p 863.

Larpent, J.P \& Gourargaud. (1997). M. Mémento technique de microbiologie (3eme édition. Lavoisier Tech \& Doc, pp173-217.

Phiri, O., P. Mumba, B.H.Z. Moyo, and W. Kadewa. (2005). "Assessment of the Impact of Industrial Effluents on Water Quality of Receiving Rivers in Urban Areas of Malawi". Int. J. Environ. Sci. Tech.. Vol.2, NO 3, pp:237-244.

Tiri, A. Boudoukha, A. Bouguerne, A. \& Lahbari, N (2007). Influence of the industrial and urban waste water on the quality of water (Case of Koudiat Medouar Watershed), J. Eng. Applied, Vol.2, N0 11, pp. 1592-159. 


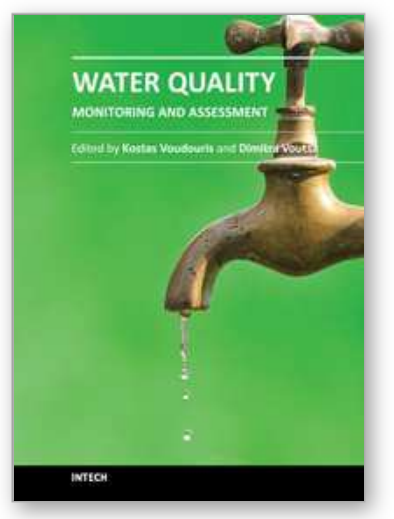

\author{
Water Quality Monitoring and Assessment \\ Edited by Dr. Voudouris
}

ISBN 978-953-51-0486-5

Hard cover, 602 pages

Publisher InTech

Published online 05, April, 2012

Published in print edition April, 2012

The book attempts to covers the main fields of water quality issues presenting case studies in various countries concerning the physicochemical characteristics of surface and groundwaters and possible pollution sources as well as methods and tools for the evaluation of water quality status. This book is divided into two sections: Statistical Analysis of Water Quality Data;Water Quality Monitoring Studies.

\title{
How to reference
}

In order to correctly reference this scholarly work, feel free to copy and paste the following:

A. Nait Merzoug and H. Merazig (2012). Water Pollution of Oued Medjerda in Algerian Souk Ahras Region, Water Quality Monitoring and Assessment, Dr. Voudouris (Ed.), ISBN: 978-953-51-0486-5, InTech, Available from: http://www.intechopen.com/books/water-quality-monitoring-and-assessment/water-pollution-of-ouedmedjerda-in-algerian-souk-ahras-region-

\section{INTECH}

open science | open minds

\author{
InTech Europe \\ University Campus STeP Ri \\ Slavka Krautzeka 83/A \\ 51000 Rijeka, Croatia \\ Phone: +385 (51) 770447 \\ Fax: +385 (51) 686166 \\ www.intechopen.com
}

\author{
InTech China \\ Unit 405, Office Block, Hotel Equatorial Shanghai \\ No.65, Yan An Road (West), Shanghai, 200040, China \\ 中国上海市延安西路65号上海国际贵都大饭店办公楼405单元 \\ Phone: +86-21-62489820 \\ Fax: +86-21-62489821
}


(C) 2012 The Author(s). Licensee IntechOpen. This is an open access article distributed under the terms of the Creative Commons Attribution 3.0 License, which permits unrestricted use, distribution, and reproduction in any medium, provided the original work is properly cited. 